\title{
Clinical and social aspects of dysmenorrhea development
}

\section{V. Pakharenko}

State Higher Educational Establishment “Ivano-Frankivsk National Medical University”, Ukraine

Dysmenorrhea is one of the most spread diseases in gynecological practice. The pathology rate is about $45-95 \%$ of menstruated women.

Aim of the research was to determine clinical and social aspects of women with dysmenorrhea.

Materials and methods. The study involved 155 women with diagnosis dysmenorrhea who formed the basic group. 55 persons had primary form of disease (the I group), 100 patients - secondary one (the II group). Control group included 30 women without pathology. Intensity of pain was determined by Visual Analogue Scale, quality of life - 36-Item Short Form Health Survey. For statistical analysis we used program Statistica 6.0.

Results. We did not find any association between employment, body mass index and development of dysmenorrhea. The number of persons with reduced physical activity was 1.86 times more in the group with dysmenorrhea $(61.94 \%)$ than among healthy individuals $\left(33.33 \% ; \mathrm{X}^{2}=7.28, \mathrm{P}=0.007 ; \mathrm{OR}=3.84, \mathrm{Cl}=1.67-8.83, \mathrm{P}=0.002\right)$. Gynecological pathology in anamnesis had only $46.67 \%$ of controls and $74.19 \%$ of basic group patients $\left(X^{2}=7.77, P=0.005 ; O R=3.29, C l=1.47-7.33, P=0.004\right)$. High rate of gynecological diseases among patients with dysmenorrhea was due to great frequency of this pathology in the women of the II group. Almost the same rate of primagravida and multigravida was also among persons in the observed groups. Duration of pain syndrome usually was 1-2 days in the I group women. Persons of the II group indicated prolonged pain syndrome during menses lasting 2-4 days. Besides this, chronic pelvic pain $\left(X^{2}=19.42, P<0.001\right.$ compared to the I group), dyspareunia and dyschezia $\left(X^{2}=5.95, P=0.03\right.$ compared to the I group), pain, which was not connected with menstrual cycle $\left(X^{2}=16.95, P<0.001\right.$ compared to the I group) were typical for patients of the II group. Most women of both groups indicated moderate intensity of pain (67.27 \% persons in the I group and $73.00 \%$ in the II). Algomenorrhea, premenstrual syndrome, heavy menstrual bleeding were mostly diagnosed in the persons with secondary dysmenorrhea. All the scores of 36-Item Short Form Health Survey were significantly decreased in basic group patients compared to controls. Index of "Bodily pain" was less by $25.56 \%$ in persons with dysmenorrhea compared with healthy individuals $(P<0.001)$. Score "Vitality" was the lowest among other indices of psychological component by $27.27 \%(P<0.001)$ compared to controls. We determined decrease of "Social Functioning" and "Role-Emotional Functioning" in women with secondary dysmenorrhea more than in patients with primary one $(P=0.049)$.

Conclusions. Among social factors that can lead to dysmenorrhea we found association of reduced physical activity with the development of pathology $(\mathrm{OR}=3.84, \mathrm{Cl}=1.67-8.83, \mathrm{P}=0.002)$. Chronic pelvic pain, dyspareunia, pain which is not related to menstrual cycle, are more common symptoms associated with secondary dysmenorrhea compared to primary one $(P<0.05)$. But there is no difference in intensity of pain between women with primary and secondary forms of pathology. Decreased quality of life is typical for women with dysmenorrhea.

\section{Клінічні та соціамьні аспекти розвитку дисменореї}

\section{А. В. Пахаренко}

Дисменорея - одне з найпоширеніших захворювань у гінекологічній практиці. Частота поширення цієї патології становить 45-95\% серед жінок, які мають менструації.

Мета роботи - встановити клінічні та соціальні аспекти жінок із дисменореєю.

Матеріали та методи. У дослідження залучили 155 жінок із діагнозом дисменорея, які становили основну групу, з них 55 осіб мали первинну форму захворювання (I група), 100 - вторинну (II група). Контрольна група - 30 жінок без цієї патології. Інтенсивність болю визначали за допомогою візуальної аналогової шкали, якість життя - опитувальника SF-36. Для статистичного опрацювання результатів використовували програму Statistica 6.0.

Результати. Не встановили зв'язок між видом зайнятості, індексом маси тіла з розвитком дисменореї. Серед жінок із дисменореєю визначили більшу в 1,86 раза кількість осіб із недостатнім фізичним навантаженням (61,94 \%), ніж серед здорових обстежених $\left(33,33 \% ; \mathrm{X}^{2}=7,28, \mathrm{p}=0,007 ; \mathrm{OR}=3,84, \mathrm{Cl}=1,67-8,83, \mathrm{p}=0,002\right)$. Гінекологічну патологію в анамнезі мали лише 46,67 \% жінок контролю проти 74,19 \% пацієнтів основної групи $\left(X^{2}=7,77, p=0,005 ;\right.$ OR = 3,29, Cl=1,47-7,33, $p=0,004)$. Висока частота гінекологічних захворювань серед хворих із дисменореєю була пов'язана зі значним відсотком цієі патології серед жінок II групи. Майже однакова частота першовагітних і повторновагітних була серед осіб у досліджуваних групах. Зазвичай тривалість больового синдрому становила 1-2 дні в жінок у I групі. Особи II групи відзначали триваліший період болю під час менструації - протягом 2-4 днів. Крім того, хронічний тазовий біль $\left(X^{2}=19,42, p<0,001\right.$ порівняно з I групою), диспауренія та дисхезія ( $X^{2}=5,95, p=0,03$ порівняно з І групою), біль, який не пов'язаний з менструальним циклом $\left(X^{2}=16,95, p<0,001\right.$ порівняно з групою I), характерні для пацієнтів у II групі. Більшість жінок двох груп мали середню інтенсивність болю (67,27 \% осіб у I групі та 73,00 \% - у II). Альгоменорея, передменструальний синдром, посилені менструальні кровотечі діагностували переважно в осіб із вторинною дисменореєю. Значення всіх шкал опитувальника SF-36 були суттєво знижені в пацієнтів основної групи порівняно з контролем. Параметр «Інтенсивність болю» був меншим в осіб із дисменореєю на 25,56 \% порівняно зі здоровими особами ( $p<0,001)$. Шкала «Життєва активність» була найменшою серед інших показників психологічного компонента - на 27,27 \% ( $p<0,001)$ порівняно з контролем. Визначили зниження показників «Соціального функціонування» та «Рольового функціонування, зумовленого емоційним станом» у жінок із вторинною дисменореєю більше, ніж у хворих із первинною формою захворювання $(p=0,049)$.
Key words: dysmenorrhea, risk factors, pain, life quality.

Zaporozhye medical journal 2018; 20 (5), 687-691 Dol: 10.14739/2310-1210 2018.5.141539

E-mail: ludapak@ukr.net

Кнючові слова: Аисменорея, фактори ризику, бікь, якість життя.

Запорізький медичний журнал. - 2018. T. 20, № 5(110). C. 687-691 
Висновки. Серед соціальних факторів, що можуть призвести до розвитку дисменореї, виявили зв'язок недостатньої фізичної активності з розвитком патології $(\mathrm{OR}=3,84, \mathrm{Cl}=1,67-8,83, \mathrm{p}=0,002)$. Хронічний тазовий біль, диспауренія, біль, що не пов'язаний із менструальним циклом, частіше спостерігають при вторинній дисменореї порівняно з первинною $(p<0,05)$. Але немає різниці за інтенсивністю болю в жінок із первинними та вторинними формами патології. Погіршення якості життя є характерним для жінок із дисменореєю.

Ключевые слова: Аисменорея, факторы риска, боль, качество жизни.

Запорожский медицинский журнал. - 2018. T. 20, № 5(110). C. 687-691

\section{Клинические и социальные аспекты развития дисменореи}

\section{А. В. Пахаренко}

Дисменорея - одно из наиболее распространенных заболеваний в гинекологической практике. Частота патологии составляет 45-95\% среди менструирующих женщин.

Цель работы - установить клинические и социальные аспекты женщин с дисменореей.

Материалы и методы. В исследование вошли 155 женщин с диагнозом дисменорея, которые составили основную группу, из них 55 человек имели первичную форму заболевания (I группа), 100 - вторичную (II группа). Контрольную группу составили 30 женщин без данной патологии. Интенсивность боли определяли с помощью визуальной аналоговой шкалы, качество жизни - опросника SF-36. Для статистической обработки результатов использовали программу Statistica 6.0.

Результаты. Не установили связь между типом занятости, индексом массы тела с развитием дисменореи. Среди женщин с дисменореей отмечено большее в 1,86 раза количество лиц с недостаточной физической нагрузкой $(61,94 \%)$, чем среди здоровых обследованных $\left(33,33 \% ; \mathrm{x}^{2}=7,28, \mathrm{p}=0,007 ; \mathrm{OR}=3,84, \mathrm{Cl}=1,67-8,83, \mathrm{p}=0,002\right)$. Гинекологическую патологию в анамнезе имели лишь 46,67 \% в контрольной группе против 74,19\% пациентов в основной $\left(X^{2}=7,77, p=0,005 ; O R=3,29\right.$, $\mathrm{Cl}=1,47-7,33, p=0,004)$. Высокая частота гинекологических заболеваний среди больных с дисменореей связана со значительным процентом этой патологии среди женщин II группы. Почти одинаковая частота первобеременных и повторнобеременных была среди лиц в исследуемых группах. Обычно продолжительность болевого синдрома составляла 1-2 дня у женщин в I группе. Лица II группы отмечали более длительный период боли во время менструации - в течение 2-4 дней. Кроме того, хроническая тазовая боль ( $x^{2}=19,42, p<0,001$ по сравнению c I группой), диспаурения и дисхезия $\left(X^{2}=5,95, p=0,03\right.$ по сравнению $\mathrm{c}$ I группой), боль, которая не связана с менструальным циклом $\left(X^{2}=16,95, p<0,001\right.$ по сравнению с группой I), характерны для пациентов во II группе. Большинство женщин двух групп указали на среднюю интенсивность боли (67,27 \% лиц в I группе и 73,00 \% - во II). Альгоменорея, предменструальный синдром, усиленные менструальные кровотечения диагностированы преимущественно у лиц со вторичной дисменореей. Значения всех шкал опросника SF-36 значительно снижены у пациентов основной группы по сравнению с контролем. Параметр «Интенсивность боли» меньше у лиц с дисменореей на 25,56 \% по сравнению со здоровыми женщинами $(p<0,001)$. Шкала «Жизненная активность» была наименьшей среди других показателей психологического компонента - на 27,27 \% ( $<<0,001)$ по сравнению с контролем. Установлено снижение показателей «Социального фуннционирования» и «Ролевого функционирования, обусловленного эмоциональным состоянием» у женщин со вторичной дисменореей больше, чем у больных с первичной формой заболевания $(p=0,049)$.

Выводы. Среди социальных факторов, которые могут привести к развитию дисменореи, установили связь недостаточной физической активности с развитием патологии $(\mathrm{OR}=3,84, \mathrm{Cl}=1,67-8,83, \mathrm{p}=0,002)$. Хроническую тазовую боль, диспаурению, боль, не связанную с менструальным циклом, чаще наблюдают при вторичной дисменорее по сравнению с первичной $(p<0,05)$. Но нет разницы по интенсивности боли женщин с первичными и вторичными формами патологии. Ухудшение качества жизни характерно для женщин с дисменореей.

\section{Introduction}

Dysmenorrhea is one of the most spread diseases in gynecological practice. A lot of women suffer from pain during menstruation. Rate of the pathology is about $45-95 \%$ of menstruated women [1]. Dysmenorrhea is classified into primary and secondary forms. Primary dysmenorrhea is related to increase in secretion of prostaglandins, leukotrienes, disorders of uterine contractility and so on [2]. Secondary dysmenorrhea usually occurs on the background of pelvic organs inflammatory diseases, endometriosis, adenomyosis and uterine myoma [3]. Pain syndrome is very often accompanied by psychological disorders. Tendency to aggressive behavior, depression, increased anxiety are typical for such patients $[4,5]$. Besides this, reduced daily activities and decreased quality of life are associated with dysmenorrhea [6-8].

Diagnosis of dysmenorrhea is based on patients' complains of menstrual pain and results of examinations. First of all, clinical management of women with dysmenorrhea includes complete examination using general and gyneco- logical ones, ultrasonography and Doppler ultrasonography of pelvic organs. Other underlying gynecological pathology must be included or excluded for differentiation of dysmenorrhea primary or secondary form [3]. Treatment of patients depends on form and cause of disease. Usually it includes hormonal therapy, non-steroidal anti-inflammatory drugs, treatment of underlying pathology [9]. There are publications showing effectiveness of physical exercises, nutrition supplements with vitamin $D$ and omega- 3 fatty acids for menses pain relief [3].

It is worth mentioning, that usually menstrual pain syndrome is not a reason to visit a gynecologist. Self-treatment using medicines which are advertised on TV or in fashion magazines is more popular among women than consultation by a doctor on this particular pathology $[10,11]$. Unfortunately, such patients do not realize all the problems that may be associated with pain syndrome. Today, the rate of gynecological diseases differs from that several decades ago when most women were screened by the government-controlled periodic health examination. So, it is important today to determine the clinical and social aspects of this problem. 


\section{The aim}

Aim of the research was to determine clinical and social aspects of women with dysmenorrhea.

\section{Materials and methods}

The study involved 155 women with diagnosis dysmenorrhea who formed the basic group. 55 persons had primary form of disease (the I group), 100 patients - secondary one (the II group). Control group included 30 women without pathology. The research was carried out in female dispensary No. 2 of Ivano-Frankivsk City Clinical Perinatal Centre.

Inclusion criteria: presence of dysmenorrhea, reproductive age, written consent from patient. Exclusion criteria: pregnancy, lactation, acute inflammatory diseases of pelvic organs, tumors of the uterus and ovaries of unknown etiology, organic pathology of the central nervous system, mental illness, malignant tumors in the present or in anamnesis, trauma of pelvic organs in anamnesis, severe form of extragenital diseases, dysmenorrhea after operations on pelvic organs, having taken psychotropic drugs in the previous three months.

All women underwent general and gynecological examination, and ultrasound echography of pelvic organs. Visual Analogue Scale (VAS) was used to determine intensity of pain (mild pain - 1-4 points, moderate $-5-6$ points, severe $-7-10$ points). Premenstrual syndrome was diagnosed with the help of anamnestic data and R. Moos Menstrual Distress Questionnaire. 36-Item Short Form Health Survey (SF-36) was used to assess quality of life.

For statistical analysis we used program Statistica 6.0. Descriptive statistics (mean, standard error of mean), nonparametric statistic (Mann-Whitney test was used to compare two independent samples), criterion $X^{2}$, odds ratio $(\mathrm{OR})$, confidence interval $(\mathrm{Cl})$ were calculated. $A$ $P$-value $\leq 0.05$ was considered as statistically significant.

\section{Results}

The average age in the control group was $27.97 \pm 0.87$ years, in the basic one $-30.78 \pm 0.44$ years $(28.75 \pm 0.78$ years in the I group, $31.90 \pm 0.50$ years - in the II $(P<0.01$ in comparison with the controls and I group)). There was no significant difference in age at menarche between women with dysmenorrhea (13.03 \pm 0.17 years) and without it (12.90 \pm 0.07 years). We did not find any association between employment and development of dysmenorrhea. Most of persons in the control and basic groups had intellectual work (students, teachers, doctors, managers and so on) - $19(63.33 \%)$ and $88(56.77 \%)$ persons, respectively. $11(36.67 \%)$ and 67 (43.23\%) individuals, respectively, were workers and housewives. Also no significant difference was found between body mass index (BMI) and pathology. Women with normal BMI predominated in both groups - 21 $(70.00 \%)$ healthy individuals and $104(67.09 \%)$ patients with dysmenorrhea. $8(26.67 \%)$ controls were overweight or had obesity, 1 (3.33\%) person was underweight. In the basic group these parameters were, respectively, 46 $(29.68 \%)$ and $5(3.23 \%)$ patients.

So, among social factors we found only importance of physical activity for dysmenorrhea development. Adequate physical activity indicated 20 (66.67\%) persons in the con- trol group and 59 (38.06\%) - in the basic one. The number of persons with low level of physical activity was 1.86 times more in the group with dysmenorrhea $(96(61.94 \%))$ than among healthy $\left(10\right.$ (33.33 \%) women; $X^{2}=7.28, P=0.007$; $\mathrm{OR}=3.84, \mathrm{Cl}=1.67-8.83, \mathrm{P}=0.002)$. There was no difference in above mentioned indices between patients of the I and II groups.

Gynecological pathology in anamnesis had only 14 (46.67 \%) controls and $115(74.19 \%)$ women in the basic group $\left(X^{2}=7.77, p=0.005 ; \mathrm{OR}=3.29, \mathrm{Cl}=1.47-7.33\right.$, $P=0.004)$. High incidence of gynecological diseases among persons with dysmenorrhea was because of great frequency of this pathology in patients of the II group. Only $15(27.27 \%)$ individuals in the I group had gynecological problems but in the II group - all of them (100 (100.00\%) persons). Most women of all groups had inflammatory diseases. Thus, $5(16.67 \%)$ healthy persons suffered from chronic adnexitis, $4(13.33 \%)$ - ovarian cysts, 9 $(30.00 \%)$ - colpitis, bacterial vaginosis, $3(10.00 \%)$ - endometriosis and 2 (6.67\%) - uterine myoma. 64 (41.29\%) patients with dysmenorrhea had chronic inflammatory diseases of pelvic organs $\left(X^{2}=5.51, P=0.02 ; O R=3.51\right.$, $\mathrm{Cl}=1.28-9.68, \mathrm{P}=0.02): 3(5.45 \%)$ patients with primary form of disease and $61(61.00 \%)$ with secondary one; $57(36.77 \%)$ - inflammatory processes of lower genital tract (colpitis, bacterial vaginosis) (18 (32.72\%) and 39 (39.00\%) individuals, respectively); 26 (16.77\%) - ovarian cysts $(6(10.91 \%)$ and $20(20.00 \%))$. In the II group 21 $(21.00 \%)$ persons had uterine myoma $\left(X^{2}=6.04, P=0.01\right.$; $\mathrm{OR}=16.50, \mathrm{Cl}=0.97-280.90, \mathrm{P}=0.05), 34(34.00 \%)-$ endometriosis $\left(X^{2}=12.11, P<0.001 ; O R=31.65\right.$, $\mathrm{Cl}=1.88-533.37, \mathrm{P}=0.02)$.

Frequency of nulligravida in all groups was approximately equal (8 (26.67\%) persons in the control group, 35 $(22.58 \%)$ - in the basic one: the I group - $17(30.91 \%)$ patients, the II - 18 (18.00\%) patients). Almost the same rate of primagravida and multigravida was also among persons in the observed groups. $13(43.33 \%)$ healthy women were primagravida, $9(30.00 \%)$ - multigravida, in the basic group - $71(45.81 \%)$ and 49 (31.61\%), respectively, (27 $(49.09 \%)$ and $11(20.00 \%)$ patients in the I group, 44 $(44.00 \%)$ and $38(38.00 \%)$ - in the II).

$20(66.67 \%)$ controls were parous women, 5 $(16.67 \%)$ - women who had a history of miscarriages and artificial abortions. These indices correspond to the parameters of women with dysmenorrhea. In the basic group $110(70.97 \%)$ patients were with parity (38 (69.09\%) - in the I group and $72(72.00 \%)$ - in the II). Artificial, missed abortions and miscarriages had $5(9.09 \%)$ persons with primary dysmenorrhea and 24 (24.00\%) - with secondary one.

The onset of dysmenorrhea was different between women of the I and II groups $-16.04 \pm 0.24$ and $22.67 \pm 0.45$ years, respectively $(P<0.001)$. The common complaints in women with dysmenorrhea were related to menstrual pain syndrome. Usually duration of pain syndrome was 1-2 days in women of the I group. Persons of the II group indicated prolonged pain syndrome during menses lasting 2-4 days. Besides this, chronic pelvic pain was typical only for the II group persons (31 (31.00\%) women) $\left(X^{2}=19.42, P<0.001\right.$ in comparison with the I group) as well as other types of pain. Dyspareunia and dyschezia had only $11(11.00 \%)$ patients with secondary dysmenorrhea $\left(X^{2}=5.95, P=0.03\right.$ compared 
Table 1. Survey of health in patients with dysmenorrhea

\begin{tabular}{|c|c|c|c|c|}
\hline & Control group $(n=30)$ & I group $(n=55)$ & II group ( $n=100$ ) & Basic group $(n=155)$ \\
\hline Bodily pain & $77.27 \pm 4.23$ & $56.29 \pm 2.62^{*}$ & $58.19 \pm 1.87^{*}$ & $57.52 \pm 1.52^{*}$ \\
\hline Physical Functioning & $85.67 \pm 3.21$ & $67.55 \pm 2.47^{*}$ & $64.50 \pm 1.77^{*}$ & $65.58 \pm 1.44^{*}$ \\
\hline Role-Physical Functioning & $70.00 \pm 5.14$ & $58.18 \pm 3.05$ & $55.25 \pm 2.44^{\circ}$ & $56.29 \pm 1.91^{\circ}$ \\
\hline General Health & $72.33 \pm 4.01$ & $65.56 \pm 3.16$ & $59.81 \pm 2.17^{\circ}$ & $61.85 \pm 1.80^{\circ}$ \\
\hline Vitality & $75.33 \pm 3.67$ & $58.36 \pm 3.84^{\circ}$ & $52.70 \pm 2.30^{*}$ & $54.71 \pm 2.02^{*}$ \\
\hline Social Functioning & $71.43 \pm 3.98$ & $60.62 \pm 3.06^{\circ}$ & $52.75 \pm 1.89^{\wedge *}$ & $55.54 \pm 1.65^{*}$ \\
\hline Role-Emotional Functioning & $80.23 \pm 4.56$ & $69.42 \pm 3.33$ & $61.08 \pm 2.08^{* \wedge}$ & $64.04 \pm 1.81^{\circ}$ \\
\hline Mental Health & $80.27 \pm 3.67$ & $67.18 \pm 3.45^{\circ}$ & $60.26 \pm 1.92^{*}$ & $62.72 \pm 1.75^{*}$ \\
\hline
\end{tabular}

$\circ$ : significance of difference of indicators compared to the control group $(\mathrm{P}<0.05)$; *: significance of difference of indicators compared to the control group $(\mathrm{P}<0.001)$;

$\wedge$ : significance of difference of indicators between the I and II groups $(P<0.05)$.

to the I group). Also $28(28.00 \%)$ women in the II group had non-menstrual pain $\left(X^{2}=16.95, P<0.001\right.$, compared with the I group).

We did not find any significant difference in pain syndrome severity according to VAS scale between persons of the I and II groups. Moderate pain intensity was indicated by most patients of both groups: (37 $(67.27 \%)$ women in the I group and $73(73.00 \%)$ - in II). $9(16.36 \%)$ individuals with primary dysmenorrhea had mild and severe intensity of pain each. $4(4.00 \%)$ patients with secondary form of disease suffered from mild pain, $23(23.00 \%)$ - from severe one.

We determined difference in dynamics of pain intensity after childbirth between women with primary and secondary form of pathology. After childbirth 27 (49.09\%) persons in I the group noted pain syndrome reduction, 11 (20.00\%) patients indicated no changes. But the number of persons with pain relief after childbirth in the II group (22 $(22.00 \%)$ was 2.23 times less than in the I group; $X^{2}=10.83, P=0.001$ ). Besides this 37 (37.00\%) women reported increase of pain intensity last months.

Combination of dysmenorrhea and algomenorrhea had $22(40.00 \%)$ individuals in the I group and $64(64.00 \%)$ - in the II ( $X^{2}=7.33, P=0.007$ compared to the I group). General weakness (19 $(34.55 \%)$ women with primary form and 47 (47.00\%) persons with secondary one), emotional lability (25 (45.45\%) and $76(76.00 \%)$ patients, respectively), sleep disorders (7 (12.73\%) and $36(36.00 \%)$ individuals) were the most common patients' with dysmenorrhea complaints during menses.

Heavy menstrual bleeding reported only $3(10.00 \%)$ healthy women, $8(14.55 \%)$ patients of the I group and 39 $(39.00 \%)$ - of the II $\left(X^{2}=7.59, P=0.006\right.$ compared to controls, $X^{2}=8.92, P=0.003$ compared to the I group). Besides this we determined that certain part of women in all groups had premenstrual syndrome: $8(26.67 \%)$ controls and 75 $(48.39 \%)$ women with dysmenorrhea $\left(X^{2}=3.96, P=0.04\right)$ $(15(27.27 \%)$ in the I group and $60(60.00 \%)$ - in the II $\left.\left(X^{2}=8.99, P=0.003\right)\right)$.

Self-management for dysmenorrhea was typical among persons of both groups. Only $12(21.82 \%)$ patients with primary form of disease consulted gynecologist about treatment. $19(34.55 \%)$ women with primary dysmenorrhea did not use medicines, 24 (43.63\%) - used self-medications (spasmolytics, analgetics, non-steroidal anti-inflammatory drugs). The number of persons with secondary dysmenorrhea who visited gynecologist was 2.52 times higher than patients with primary one $(55(55.00 \%)$ individuals; $\left.X^{2}=14.59, P<0.001\right)$. They consulted doctor mostly not because of pain during menstruation. The main reasons for such visits were related to underlying gynecological diseases.

All the scores of 36-Item Short Form Health Survey were significantly decreased in women of the basic group compared to controls (Table 1). Among physical component attention should be paid to "Bodily pain" which was less in persons with dysmenorrhea by $25.56 \%$ compared to healthy individuals $(P<0.001)$. Score "Vitality" was the lowest among other indices of psychological component - by $27.27 \%(P<0.001)$ compared to controls. There was no significant difference between patients with primary and secondary dysmenorrhea in physical component indices. But scores of psychological component were lower in women of the II group than of the I group. Thus, we determined more severe reduction of "Social Functioning" and "Role-Emotional Functioning" in women with secondary dysmenorrhea as compared to women with primary one $(\mathrm{P}=0.049)$ (Table 1).

The underlying pathology is often resulting in secondary dysmenorrhea. The main causes of it are endometriosis, chronic pelvic inflammatory diseases. Various types of pain as dyspareunia, noncyclic pain, different forms of intensity and duration are typical for such gynecological diseases [3]. It has been well determined that pain syndrome is associated with the influence on activity of life reduction [12]. That is why decrease in scores of physical component that was demonstrated in our research is representative for both primary and secondary forms of pathology. Besides the pain syndrome influence on physical part of quality of life, some publications indicate that patients with dysmenorrhea are very often in the risk group of mental health problems development such as depression, sleep disorders, aggressive mood, anxiety $[4,5]$. We believe that underlying pathology of secondary dysmenorrhea has a profound impact on the psychological condition of patients.

\section{Conclusions}

1. Among social factors that can lead to dysmenorrhea we found association of reduced physical activity with the development of pathology $(\mathrm{OR}=3.84, \mathrm{Cl}=1.67-8.83$, $P=0.002)$. There are no associations between body mass index, type of employment and dysmenorrhea.

2. Type of pain and its duration depend on form of dysmenorrhea. Chronic pelvic pain, dyspareunia, pain which is not related to menstrual cycle are more common symptoms associated with secondary dysmenorrhea compared to primary one $(P<0.05)$. But there is no difference in intensity 
of pain between women with primary and secondary forms of pathology.

3. The quality of life is decreased in women with dysmenorrhea. Scores of physical components of SF-36 are similarly decreased in patients with primary and secondary dysmenorrhea. Reduction in psychological scores is more significant in secondary form of the disease.

Prospects for further research in this direction. In the future, we expect to study different types of treatment for patients with dysmenorrhea.

Conflicts of Interest: author has no conflict of interest to declare. Конфлікт інтересів: віАсутній.

Information about author:

Pakharenko L. V., MD, PhD, DSc, Associate Professor, Professor of the Department of Obstetrics and Gynecology, State Higher Educational Establishment "Ivano-Frankivsk National Medical University", Ukraine.

\section{Відомості про автора:}

Пахаренко $\Lambda$. В., А-р меА. наук, Аоцент, професор каф. акушерства та гінекології, АВНЗ «вано-Франківський національний медичний університет", Україна.

\section{Сведения об авторе:}

Пахаренко А. В., А-р меА. наук, Аоцент, профессор

каф. акушерства и гинекологии, ГВУЗ “Ивано-Франковский

национальный медицинский университет, Украина.

НаАійшла Ао реАакції / Received: 19.12.2017

Після Аоопрацювання / Revised: 14.01.2018

Прийнято Ао Аруку / Accepted: 24.01.2018

\section{References}

[1] lacovides, S., Avidon, I., \& Baker, F. C. (2015). What we know about primary dysmenorrhea today: a critical review. Hum Reprod Update, 21(6), 762-778. doi: 10.1093/humupd/dmv039.

[2] Bernardi, M.. Lazzeri, L., Perelli, F., Reis, F. M. \& Petraglia, F. (2017). Dysmenorrhea and related disorders. F1000Res, 6, 1645. doi: 10.12688/ f1000research.11682.1.

[3] Osayande, A. S., \& Mehulic, S. (2014). Diagnosis and initial management of dysmenorrhea. Am Fam Physician, 89(5), 341-346.

[4] Balık, G., Ustüner, I., Kağıtcı, M., \& Sahin, F. K. (2014). Is there a relationship between mood disorders and dysmenorrhea? J Pediatr Adolesc Gynecol, 27(6), 371-374. doi: 10.1016/.jpag.2014.01.108.

[5] Bahrami, A., Sadeghnia, H., Avan, A., Mirmousavi, S. J., Moslem, A., Eslami, S., et al. (2017). Neuropsychological function in relation to dysmenorrhea in adolescents. Eur J Obstet Gynecol Reprod Biol, 215, 224-229. doi: 10.1016/j.ejogrb.2017.06.030.

[6] Al-Jefout, M., Seham, A. F., Jameel, H., Randa, A. Q., Ola, A. M., Oday, A. M. \& Luscombe, G. (2015). Dysmenorrhea: Prevalence and Impact on Quality of Life among Young Adult Jordanian Females. J Pediatr Adolesc Gynecol, 28(3), 173-185. doi: 10.1016/j.jpag.2014.07.005.

[7] Tomás-Rodríguez, M. I., Palazón-Bru, A. Martínez-St John, D. R. Navarro-Cremades, F., Toledo-Marhuenda, J. V., \& Gil-Guillén, V. F. (2017). Factors Associated with Increased Pain in Primary Dysmenorrhea: Analysis Using a Multivariate Ordered Logistic Regression Model. J Pediatr Adolesc Gynecol, 30(2), 199-202. doi: 10.1016/j. jpag.2016.09.007.

[8] Potur, D. C., Bilgin, N. C., \& Komurcu, N. (2014). Prevalence of dysmenorrhea in university students in Turkey: effect on daily activities and evaluation of different pain management methods. Pain Manag Nurs, 15(4), 768-777. doi: 10.1016/j.pmn.2013.07.012.

[9] Amiri Farahani, Ë. L., Hasanpoor-Azghdy, S. B., Kasraei, H. \& Heidari, T. (2017). Comparison of the effect of honey and mefenamic acid on the severity of pain in women with primary dysmenorrhea. Arch Gynecol Obstet, 296(2), 277-283. doi: 10.1007/s00404-017-4409-6.

[10] De Sanctis, V., Soliman, A., Bernasconi, S., Bianchin, L., Bona, G., Bozzola, M., et al. (2015). Primary Dysmenorrhea in Adolescents: Prevalence, Impact and Recent Knowledge. Pediatr Endocrinol Rev, 13(2), 512-520.
[11] Chen, C. X., Kwekkeboom, K. L., \& Ward, S. E. (2016). Beliefs About Dysmenorrhea and Their Relationship to Self-Management. Res Nurs Health, 39(4), 263-276. doi: 10.1002/nur.21726.

[12] lacovides, S., Avidon, I., Bentley, A., \& Baker, F. C. (2014). Reduced quality of life when experiencing menstrual pain in women with primary dysmenorrhea. Acta Obstet Gynecol Scand, 93(2), 213-217. doi: $10.1111 /$ aogs. 12287 